\title{
Integrating eHealth in HIV/AIDS intervention programmes in South Africa
}

\begin{tabular}{|c|c|}
\hline \multicolumn{2}{|c|}{$\begin{array}{l}\text { Authors: } \\
\text { Babasile D. Osunyomi }{ }^{1} \\
\text { Sara (Saartjie) S. Grobbelaar }{ }^{1}\end{array}$} \\
\hline \multicolumn{2}{|c|}{$\begin{array}{l}\text { Affiliations: } \\
{ }^{1} \text { Department of Engineering } \\
\text { and Technology } \\
\text { Management, Graduate } \\
\text { School of Technology } \\
\text { Management, University of } \\
\text { Pretoria, South Africa }\end{array}$} \\
\hline \multicolumn{2}{|c|}{$\begin{array}{l}\text { Correspondence to: } \\
\text { Sara Grobbelaar }\end{array}$} \\
\hline \multicolumn{2}{|c|}{$\begin{array}{l}\text { Email: } \\
\text { s.grobbelaar@gmail.com }\end{array}$} \\
\hline \multicolumn{2}{|c|}{$\begin{array}{l}\text { Postal address: } \\
\text { Graduate School of } \\
\text { Technology Management, } \\
\text { Lynnwood Drive, Pretoria } \\
\text { 0001, South Africa }\end{array}$} \\
\hline \multicolumn{2}{|c|}{$\begin{array}{l}\text { Dates: } \\
\text { Received: } 02 \text { July } 2014 \\
\text { Accepted: } 17 \text { Nov. } 2014 \\
\text { Published: } 27 \text { Mar. } 2015\end{array}$} \\
\hline \multicolumn{2}{|c|}{$\begin{array}{l}\text { How to cite this article: } \\
\text { Osunyomi, B.D. \& Grobbelaar, } \\
\text { S.S., 2015, 'Integrating } \\
\text { eHealth in HIV/AIDS } \\
\text { intervention programmes in } \\
\text { South Africa', South African } \\
\text { Journal of Information } \\
\text { Management } 17(1) \text {, Art. } \\
\text { \#623, } 10 \text { pages. http://dx.doi. } \\
\text { org/10.4102/sajim.v17i1.623 }\end{array}$} \\
\hline \multicolumn{2}{|c|}{$\begin{array}{l}\text { Copyright: } \\
\text { C 2015. The Authors. } \\
\text { Licensee: AOSIS } \\
\text { OpenJournals. This work is } \\
\text { licensed under the Creative } \\
\text { Commons Attribution } \\
\text { License. }\end{array}$} \\
\hline \multicolumn{2}{|l|}{ Read online: } \\
\hline 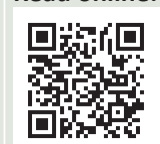 & $\begin{array}{l}\text { Scan this QR } \\
\text { code with your } \\
\text { smart phone or } \\
\text { mobile device } \\
\text { to read online. }\end{array}$ \\
\hline
\end{tabular}

Background: With an estimated $12.2 \%$ of its population infected in 2012, South Africa has the highest percentage of people living with the human immunodeficiency virus and acquired immunodeficiency syndrome (HIV/AIDS) in the world. Although the mortality rate of the epidemic is decreasing, it has adverse impacts on the socio-economic development status and human capital of South Africa.

Objective: The key aim of this article is to explore the status quo of the implementation of information and communication technologies (ICTs) in selected intervention programmes in the South African HIV/AIDS care delivery value chain. The contribution of this article is the mapping of key intervention activities along an HIV care value chain and to suggest a roadmap towards the integration of ICTs in service delivery programmes.

Method: 20 managers of HIV/AIDS intervention programmes were surveyed, followed by semi-structured in-depth interviews with these respondents. A further five in-depth interviews were conducted with experts in the ICT area for exploring the uses of and barriers to integrating ICTs in the HIV / AIDS care delivery value chain.

Results: The researchers mapped the barriers to implementation and ICT tools utilised within the HIV / AIDS care delivery value chain, which proves to be a useful tool to explore the status quo of technology in such service delivery programmes. The researchers then considered the wider policy environment and provided a roadmap based on the analysis and the South Africa eHealth strategy for driving development in this sector.

Conclusion: The authors found that South Africa's eHealth environment is still nascent and that the South African eHealth strategy does not place enough emphasis on systems integration and stakeholder engagement or the planning and process of uptake of ICTs by target audiences.

\section{Introduction and problem statement}

The prevalence of the human immunodeficiency virus and acquired immunodeficiency syndrome (HIV/AIDS) epidemic in South Africa (SA) is at $12.2 \%$ of the population, which accounts to 6.4 million individuals living with the virus (Shisana et al. 2014). The devastating effect of the HIV / AIDS epidemic is not only evident in the reduced life expectancy of South Africans (52.6 years) but also negatively affects the country's economy and the development of human capital (Bollinger \& Stover 1999; Kaiser Family Foundation 2012; UNDP 2010).

In the South African context, various historical and contextual factors affect the extent to which the country is able to effectively respond to the epidemic:

- From the political context: 'Denialism' of the gravity and impact of the HIV / AIDS pandemic in the 1990s, the resultant undermining of antiretroviral (ARV) rollout and inequalities in power and authority led to poor management of the disease at the governmental level (Knight 2006; Marais 2005).

- From the socio-economic context: This is characterised by a high unemployment rate and endemic poverty, poor service delivery in municipalities outside large centres coupled with insufficient funding made available to combat the disease (Ntuli et al. 2003; Venter 2013). HIV/AIDS is also highly stigmatised which makes reaching affected people more difficult (Eba 2007; Ntuli et al. 2003). The South African healthcare context is furthermore characterised by limited and geographical inequalities in access to healthcare services and skills (Department of Health [DOH] 2011; Health Charter 2005; Lawn \& Kinney 2009; Ntuli et al. 2003).

- Technologically, although South Africa has the most advanced ICT platform in Africa there is a digital divide between urban and rural settings and between the rich and poor 
(Akinsola, Herselman \& Jacobs 2005; Sikhakhane \& Lubbe 2005; World Economic Forum 2012). There are also different levels of eHealth maturity across and within provinces with a wide range of legacy information systems, which leads to little or no interoperability and communication between these systems (DOH 2012a, 2012b).

Thus far, research has shown that education alone is not adequate to effect the desired behavioural change amongst most individuals (Rachel 1999). ICTs have the potential to accelerate the development and implementation of productive HIV prevention programmes and interventions, by building a capable health system, thereby reducing barriers in accessing quality services (Scheibe, Brown \& Bekker 2012).

The key aim of this article is to explore the range of barriers to integrating eHealth applications in selected South African HIV/AIDS service delivery programmes. To this end the authors developed an HIV/AIDS care delivery value chain framework and explored how service delivery can be strengthened through ICTs. Following this, the focus of the analysis was on the programme level and the review entailed uncovering issues in utilising ICTs faced by practitioners in a range of HIV/AIDS service delivery programmes.

By mapping suggestions that have been made by HIV / AIDS intervention programme staff as well as ICT specialists, the authors draw some conclusions on how activities along the HIV/AIDS care delivery value chain can be strengthened through ICTs. The aim is to draw conclusions from this analysis for the eHealth policy environment and develop an implementation roadmap.

\section{Literature review}

\section{Introducing the HIV/AIDS care delivery value chain framework}

With the specific focus of this article on the status quo of the services and applications component, the article draws on the integrated product and services management system model by Weeks (2012). The authors mapped the various categories of the HIV / AIDS value chain framework and populated the activities column. Table 1 forms the basis of the framework against which the analysis of intervention programmes and the status quo of ICT support mechanisms on South African HIV/AIDS service delivery programmes will be mapped (Porter 2010:26).

\section{The role of ICTs in supporting healthcare delivery}

The roles and benefits of supporting activities in the health sector with technological mechanisms have been acknowledged in the literature (Geers \& Page 2007). De Tolly and Alexander (2009) state that there exist significant opportunities in South Africa for adopting ICTs and in particular mobile technologies to aid initiatives in the HIV/ AIDS sector.

With the focus on ICTs as an enabler of health service delivery, Table 2 provides a breakdown of various eHealth tools available to support health programme delivery.

Table 2 outlines identified information system tools which include discussion forums, blogs, social networking sites, collaborative websites and virtual networks. These tools could be useful in the wide dissemination of useful health information by providers to patients and the wider

TABLE 1: The HIV/AIDS value chain for service delivery and care.

\begin{tabular}{|c|c|c|}
\hline Value chain component & Goals to be achieved in this category & Activities towards achieving goal \\
\hline Advocacy, prevention and screening & $\begin{array}{l}\text { Permanently prevent the transmission of the HIV/AIDS virus from an infected } \\
\text { individual to an uninfected individual. }\end{array}$ & $\begin{array}{l}\text { Identify high-risk individuals } \\
\text { Conduct HIV tests } \\
\text { Promote risk reduction strategies } \\
\text { Modify behavioural risk factors } \\
\text { Connect patients with primary care systems } \\
\text { Create medical records }\end{array}$ \\
\hline Diagnosis and staging & $\begin{array}{l}\text { Detailed result of the individual's HIV/AIDS status: the stage of the infection is } \\
\text { determined. The aim of this stage is to device a treatment management plan } \\
\text { for the individual. }\end{array}$ & $\begin{array}{l}\text { Formal diagnosis and staging } \\
\text { Determine transmission method } \\
\text { Identify others at risk } \\
\text { Create a management plan } \\
\text { Formulate a treatment plan }\end{array}$ \\
\hline Medical management & $\begin{array}{l}\text { Develop an adequate medical intervention management plan that reduces } \\
\text { the progression of the disease, through nutritional interventions and a rapid } \\
\text { prevention and intervention of opportunistic infections. }\end{array}$ & $\begin{array}{l}\text { Initiate therapies to delay onset } \\
\text { Treat co-morbidities that affect progression } \\
\text { Improve patient awareness } \\
\text { Connect patient to care team }\end{array}$ \\
\hline Intervening measures & $\begin{array}{l}\text { Promote early intervention plans for the infected individual, by improving } \\
\text { adherence to first-line drug therapy and to slow the emergence of drug } \\
\text { resistance. }\end{array}$ & $\begin{array}{l}\text { Initiate ARV therapy } \\
\text { Prepare patients for disease progression and side effects } \\
\text { of treatment } \\
\text { Manage secondary infections and associated illnesses }\end{array}$ \\
\hline Disease management & $\begin{array}{l}\text { Continuous plans and support for patient's adherence to medications, need for } \\
\text { social assistance, nutritional support, patient's clinical status and monitoring } \\
\text { of the risk of transmitting the virus to an uninfected person. }\end{array}$ & $\begin{array}{l}\text { Manage the effects of associated illnesses } \\
\text { Manage the side effects of ARV therapy } \\
\text { Determine additional nutritional needs } \\
\text { Prepare patient for end-of-life management } \\
\text { Primary care and health maintenance }\end{array}$ \\
\hline Managing complications & $\begin{array}{l}\text { Provides required care to facilitate recovery from deteriorations in the } \\
\text { patient's clinical status and to provide additional support. }\end{array}$ & $\begin{array}{l}\text { Initiate drug therapies } \\
\text { Manage acute illness } \\
\text { Manage infection } \\
\text { Manage side effects } \\
\text { Provide additional support }\end{array}$ \\
\hline
\end{tabular}


TABLE 2: Information system for health care providers and consumers.

\begin{tabular}{|c|c|}
\hline Providers & Patients and wider public \\
\hline \multicolumn{2}{|l|}{ Individual electronic health information } \\
\hline Discussion forums & Media platforms (radio and television) \\
\hline Blogs & Online social support programmes \\
\hline Social networking sites & Discussion forums \\
\hline Collaborative websites & Blogs \\
\hline \multirow[t]{2}{*}{ Virtual worlds } & Social networking sites \\
\hline & Virtual worlds \\
\hline \multicolumn{2}{|l|}{ Information systems for disease management } \\
\hline Electronic health records & Directories of health care professionals and institutions \\
\hline Patient information systems & Health information (either a spectrum of searchable information or \\
\hline Hospital information systems & more narrowly defined content) \\
\hline General practitioner information systems & Personal health records or health care information system \\
\hline National electronic registries & Patient Web portal \\
\hline \multicolumn{2}{|l|}{ General information systems } \\
\hline \multicolumn{2}{|l|}{ ARTIS } \\
\hline \multicolumn{2}{|l|}{ Health management information systems } \\
\hline Distance learning and electronic resources & \\
\hline
\end{tabular}

TABLE 3: Disease management delivery tools and support tools for policymakers.

Providers
Remote diagnosis, point-of-care technology
Transaction processing
Clinical decision support system
Appointment booking and management
Service delivery
Supply chain planning and collaboration
Order tracking and delivery coordination
Telehealth, mHealth
E-prescription (prescription and test ordering support)
Electronic referrals and specialist letters
Electronic health events summariss, prescriptions and test ordering
Medications management
Alerts monitoring and management
Chronic disease management
Clinical decision support
Adverse event monitoring

Patients and wider public

Patient Web portal

Telemonitoring

Home monitoring and messaging system

Smartphone applications

Email and SMS

Pagers

Policymakers and health programme management

Risk analysis

Compliance monitoring and reporting

Performance monitoring of servive providers and programmes

Skills evaluation

Healthcare operations management

Clinical practice improvement

Health programme design and optimisation

Health policy development

Clinical research

Rapid access to information for disease surveillance and modelling

public at a reasonable cost and also support learning, communication and dissemination of information between service providers.

Information systems (also shown in Table 2) may ensure effective disease management and provide the means to monitor, control and evaluate the geographical spread of the disease. It also could be used to track the timely distribution of life-saving resources to patients and also to monitor, evaluate and ensure the constant availability of resources. The tools identified in this section include patient information systems, hospital information systems, general practitioner information systems, national electronic registries, national drug registries, general information systems, antiretroviral information systems, health management information systems, distance learning and electronic resources.

As far as disease management delivery tools are concerned (Table 3), these ICTs may be employed to ensure effective delivery of services. Again a series of tools can be identified that apply to service providers, patients and the wider public as well as policymakers.

The tools highlighted in Table 3 can be useful in ensuring proper diagnosis of diseases irrespective of the patient's location, provide service providers with effective decisionmaking tools, create an adequate strategy and plan in managing the disease, monitor resources, ensure proper prescriptions of drugs and provide productive service delivery to target recipients.

Also, the benefits of integrating supply chain management capacity through ICT infrastructure are to facilitate effective transaction processing, to promote supply chain planning and collaboration and to coordinate order tracking and delivery (Aurumo, Inkilainen \& Kauremaa 2005). Through such mechanisms, ICT infrastructure could support constant availability of ARVs and other vital resources, providing 
an effective means of estimating the quantities of resources to be ordered and to monitor factors that could hinder the operations of the programs (Chandani 2006).

On the policy side, design and support for HIV intervention programmes deployed should be directed through detailed understanding and mapping of the epidemiology of HIV for designing an appropriate mix of prevention programmes. As discussed, ICTs can be employed as enabling mechanisms in monitoring and tracking healthcare service delivery and the overall performance of the health system (DOH 2012a). The next step is now to proceed to introduce an overarching policy framework for eHealth and the implications that may have on the development of a strategy and implementation thereof in South Africa.

\section{A policy framework and review of services and applications for eHealth systems}

The World Health Organisation (WHO) and International Telecommunication Union (ITU) have developed a toolkit for providing guidance to the development of a national eHealth strategy (WHO 2012). This to a large extent has informed the South African eHealth strategy, which will support the development of an eHealth system over the medium term.

Drawing on the WHO's document as well as a review of the South African eHealth policy's compliance to these guidelines, the authors outline the key components for such a strategy (Foster 2012). The purpose of this is to provide a larger policy framework within which to place the primary research findings for this study and to highlight the barriers to using ICTs at present on a practical level. See Figure 1.

A range of coordination related components have been identified that need to be included in the capacity development of supporting and eHealth environment (WHO 2012) (see Figure 1):

- Theleadershipand governance component includes activities to coordinate the initiative, engage with stakeholders, manage operations and monitor and evaluate outcomes of programmes.

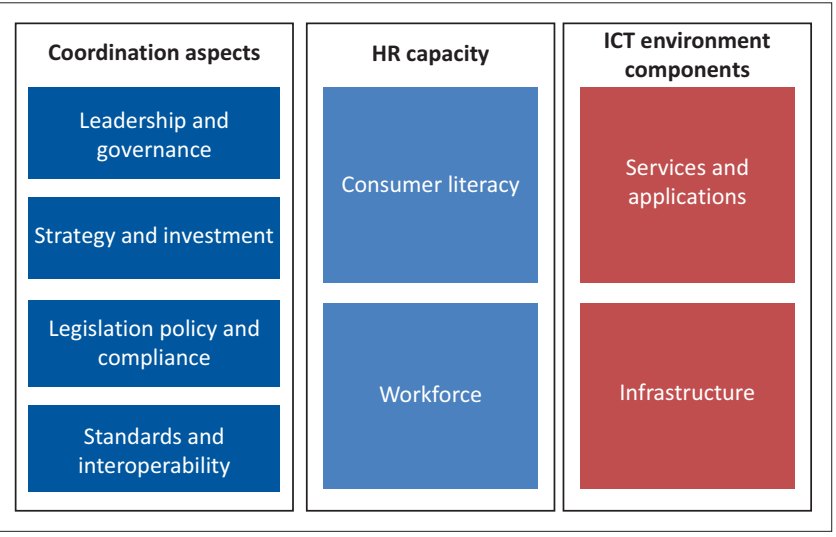

FIGURE 1: Summary of components of an eHealth strategy.

Source: Adapted from World Health Organization (WHO), 2012, National eHealth strategy toolkit, viewed 10 February 2014, from https://extranet.who.int/iris/restricted/ handle/10665/75211
- The strategy and investment component includes strategic planning for the creation of an enabling environment considering financing and funding mechanisms and investment support aligned with national priorities.

- The legislation, policy and compliance component includes the aspects of the policy environment to legislate and regulate the use of and access to data and the development of the eHealth environment and to regulate standards compliance.

- The standards and interoperability component refers to the range of standards that will need to be adopted to ensure interoperability of various systems and enable the exchange of information between them.

Human resource capacity development aspects identified in the toolkit are:

- Workforce: This ensures that the necessary eHealth knowledge and skills are available through internal expertise, technical cooperation or partnership with the private sector and also the development of effective eHealth education and training programmes to build an adequate health workforce.

- Consumer literacy: Although not included as a separate component in the WHO toolkit, given the SA environment and developing country context, the authors include electronic literacy and user-friendliness as a crucial aspect of the development of a system (WHO 2012).

ICT environment components identified in the toolkit are:

- Infrastructure, which refers to the physical infrastructure that is required to support exchange of information across geographical and health sector boundaries.

- Services and applications, which includes the actual implementation of ICT tools for eHealth and the software applications through which they are delivered.

The South African eHealth strategy places much emphasis on eHealth maturity of the South African health system. Various stages of readiness for a health system are considered, mostly based on the readiness of the system to transition to an eHealth environment looking at data flow and collection, data utilisation and integration, resource capacity and scope and scale. The objectives of the South African eHealth strategy covers improvements on existing ICT platforms, development of a novel platform and a plan for further research and development in the utilisation of ICT infrastructure (DOH 2012a, 2012b).

Scrutinising the range of challenges that have been outlined in the strategy for the South African environment (DOH 2012a, 2012b), it is clear that they are mostly centred along a need to coordinate and to develop partnerships and alliances. This is required to overcome disparities in systems such as different levels of eHealth maturity, disparate information systems in provinces with no interoperability and various silos of information (DOH 2012a, 2012b).

There are also low levels of cooperation and collaboration across sectors and stakeholder groups. Furthermore, a 
wide range of different structures exist for ICT support in the various provinces. As a key enabler towards operability the strategy highlights the need for ensuring standards is in place. Issues around inequality are also raised such as inequity of expenditure and access to healthcare and broadband connectivity (DOH 2012a, 2012b).

Foster (2012) found that, in general, the South African eHealth strategy complies with the guidelines as outlined by the WHO (2012). Foster however found that the stakeholder management and engagement aspect in developing the study has not been dealt with effectively in the document.

\section{Research method and design}

The methodology used for the study is a mixed method approach. Semi-structured in-depth interviews were conducted with practitioners in HIV management organisations and specialists in the ICT and healthcare technology management fields.

The interview participants were chosen from various HIV intervention programmes all across South Africa and fell into two categories:

- Category A: Semi-structured interviews were conducted with health care practitioners and professionals from 20 HIV management organisations. The aim of these interviews was to achieve an in-depth view of the status quo of utilising ICTs in selected intervention programmes in South Africa. Topics covered during this discussion included the level of utilisation, benefits from utilisation, challenges experienced and the perceived effectiveness of the employment of ICT tools in delivery programmes.

- Category B: Semi-structured interviews were conducted with five experts in the ICT and health technology management field. These interviews provided us with a view of the potential improvements and requirements for the expansion of the utilisation of ICTs to support HIV/ AIDS intervention programmes.

During the course of the research study, the authors also completed an extensive review of each participating organisation's website to know more about their programmes and the activities covered and how the activities fit into the HIV / AIDS care delivery value chain framework.

As explained in the literature review, the objective of the devised HIV care value chain framework is to guide the analysis against an established framework in order to ensure that services can be designed and shortcomings of the system in supporting the implementation of ICTs in programmes can be analysed (Rhatigan et al. 2009; UNAIDS 2011).

In terms of the spread of organisations that were interviewed, it was ensured that the geographical representation included projects running on the city or town level (11 interviews),
TABLE 4: Sample description.

\begin{tabular}{lccc}
\hline Location & $\boldsymbol{N}$ & ICTs used & No ICTs used \\
\hline Rural & 9 & 1 & 8 \\
Urban & 11 & 11 & 0 \\
\hline Total & $\mathbf{2 0}$ & $\mathbf{1 2}$ & $\mathbf{8}$ \\
\hline
\end{tabular}

ICTs, information and communication technologies

TABLE 5: Distribution of intervention programmes' activities around HIV/AIDS.

\begin{tabular}{lccc}
\hline Row labels & Rural & Urban & Total \\
\hline Prevention and screening & 5 & 9 & $\mathbf{1 4}$ \\
Counselling & 5 & 6 & $\mathbf{1 1}$ \\
Diagnosis and staging & 6 & 6 & $\mathbf{1 2}$ \\
Medical management & 1 & 5 & $\mathbf{6}$ \\
Intervening measures & 2 & 5 & $\mathbf{7}$ \\
Disease management & 5 & 5 & $\mathbf{1 0}$ \\
Managing complications & 5 & 4 & $\mathbf{9}$ \\
Advocacy & 0 & 5 & $\mathbf{5}$ \\
Science of HIV & 0 & 4 & $\mathbf{4}$ \\
\hline
\end{tabular}

district level (three interviews), provincial level (three interviews) and national level (three interviews). This is important as it was expected that the types of activities as well as nature of challenges to utilise ICTs may differ across these projects.

\section{Results and discussion}

As shown in Table 4, the research interviews revealed that 12 out of the 20 participating programmes employ ICT tools in enhancing their intervention programmes, whilst eight indicated that they do not utilise any ICT tools. Nine of the 20 participating programmes serve rural communities, whilst the remaining 11 serve urban settings. Important to note is that eight of the nine HIV care programmes in rural programmes do not utilise ICTs in their delivery programmes whereas the programmes surveyed that operate in urban areas all utilise ICTs.

Table 5 shows the range of activities covered by the participating programmes along the stages of the HIV/ AIDS care delivery value chain (as discussed in the literature review). We have segmented the responses according to rural and urban target areas. The value chain areas covered by each of the interventions may be explained by the various focus areas of the programmes.

It can be concluded from inspecting the distribution of responses in Table 5 that the urban interventions contained in the sample tend to be more comprehensive programmes as many of them provide services along the HIV/AIDS care delivery value chain. A good number of them are also programmes that have provincial or national reach, which then implies that it is also common for these programmes to be better resourced and have access to crucial infrastructure and skills.

As shown in Figure 2, the eight organisations that do not employ ICT tools indicated that the rural location of their organisation, inadequate access to funding, inadequate access to required ICT infrastructure, a lack of ICT knowledge and 


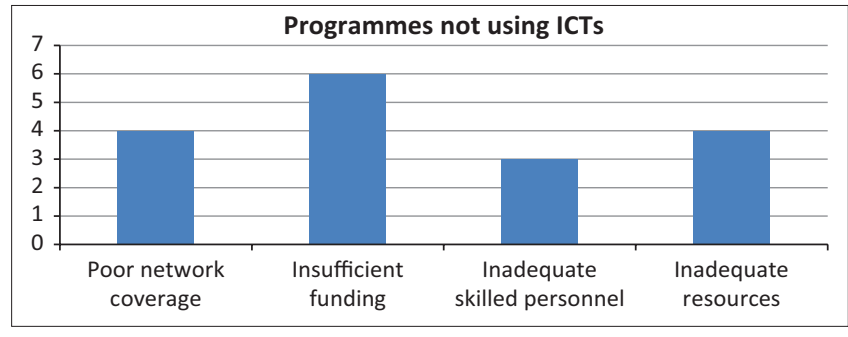

FIGURE 2: Barriers to the use of information and communication technologies in HIV/AIDS management programmes $(N=20)$.

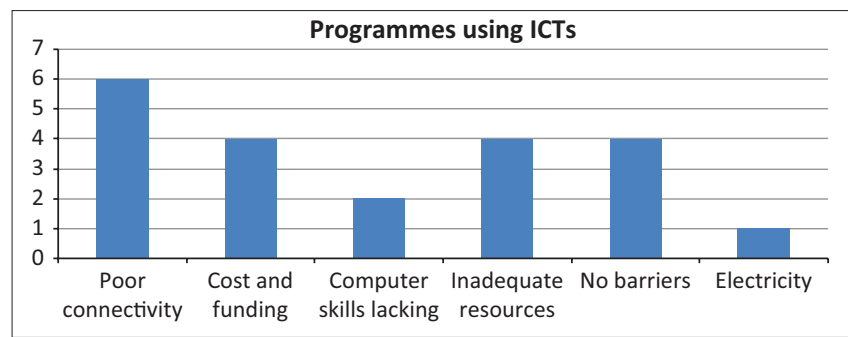

FIGURE 3: Barriers to the use of information and communication technologies in HIV/AIDS management programmes $(N=20)$.

insufficient human capital are the key barriers encountered within their organisation's ICT implementation strategy. This finding is in line with reports in the literature on the digital divide between urban and rural areas; this may however furthermore also be due to the nature of the programmes, which are usually smaller, localised programmes with limited resources.

The in-depth interviews with ICT experts also highlighted a range of barriers to the implementation of the ICTbased intervention programmes, many of which were to do with the creation of an enabling environment through ensuring privacy and confidentiality of patient information, support for adhering to current legal, clinical and ethical guidelines and obtaining informed consent from patients prior to the implementation of ICT tools. Furthermore, they highlighted financial implications, inadequate ICT supporting infrastructure and insufficient access to skilled ICT professionals.

As reflected in Figure 3, organisations that do use ICT tools to enhance their programmes identified barriers to implementation including poor connectivity, the varying levels of maturity of infrastructure, capabilities and systems across South Africa, lack of computer knowledge and skills and inadequate resources, whilst four organisations indicated that their organisation is not experiencing any barriers with utilising ICT tools and technologies.

The benefits identified by the ICT experts interviewed included improved adherence to ARV therapy, adequate and unified information databases, improved reach of coverage, global connectedness to information and expertise, easy access to useful information and facilities, effective drug dispensing and distribution, improved data gathering capacity and improved awareness in target populations about the epidemic (see Figure 4).

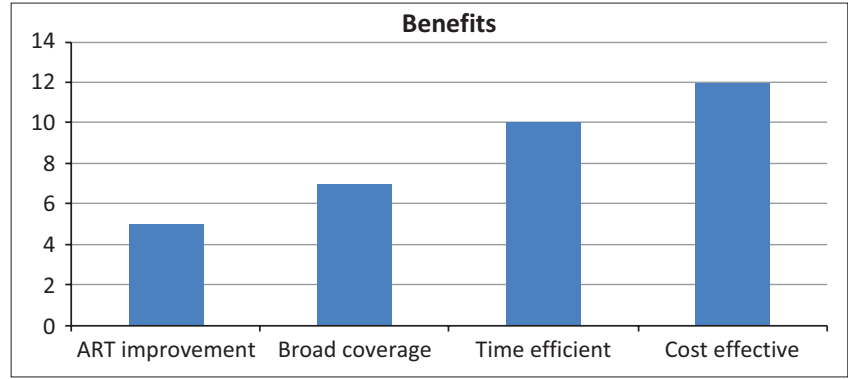

FIGURE 4: Benefits of employing information and communication technology tools in HIV/AIDS management programmes $(N=12)$.

We therefore progress to map the various ICTs that were indicated by the respondents during the interview process; these tools are mapped and compared along the range of activities in the HIV/AIDS care delivery value chain.

When considering inputs gained from ICT experts as well as comparing the ICT tools used by the HIV management organisations with the potential ICT tools suggested by the ICT and health care technology management experts in Figure 4, it was confirmed that for the programmes studied, the implementation of ICTs is still nascent. Applications such as mobile applications for HIV / AIDS, pharmaceutical information systems and a national HIV/AIDS database for monitoring, controlling and managing the epidemic are yet to be employed on a large scale in the programmes reviewed.

\section{Limitations of the study}

The key limitation of this study is that due to time and resource constraints the researchers could only conduct in-depth interviews with $20 \mathrm{HIV}$ intervention programme managers. The findings were however supplemented through interviews with five ICT and health care experts in order to ensure that the finding from the interviews may be tested against their expert knowledge and linked to a larger policy framework.

Although the authors believe that the value chain mapping is a useful approach, future studies should aim to do a more comprehensive mapping of the various barriers and facilitators of uptake of ICTs in HIV/AIDS intervention programmes.

\section{Conclusion}

The researchers found that although the South African government has identified eHealth as a priority and developed an eHealth strategy that does address the range of components as suggested by best practice, implementation is lagging. The primary data gathering and analysis process revealed that the implementation of ICTs to support HIV / AIDS programmes and their interventions are still in a nascent phase. Issues to be addressed for the large-scale roll-out of an eHealth system are typical of those 
of a country that is in the developing and building up phase of an eHealth system (WHO 2012).

Although South Africa has a well-developed ICT environment and sectors such as banking and e-commerce are well developed, eHealth implementation is lagging due to a range of issues and practical problems more specifically related to coordination and governance. Furthermore, major constraints identified revolve around privacy issues, the massive cost implications of the implementation of a countrywide ICT platform, inadequate ICT infrastructure and resources and lack of required knowledge and skills.

A key finding (in line with the South African eHealth strategy) is that a major priority remains the integration of existing systems on a provincial and national level. This also needs to be mindful of the large disparities between systems on the provincial level, availability of funding and varying maturity levels of eHealth systems across the country. Key enablers towards this end uncovered in the research include:

- There remains a lack of standards and a coordinated approach to ICT or eHealth tool development, evaluation and dissemination.

- The key concern around privacy, security and confidentiality needs to be addressed to develop public trust in these tools.

- Monitoring and evaluation of the systems need to be ensured for learning and ongoing quality assurance of services.

We therefore conclude that an effective ICT governance structure is needed to assume responsibility for establishing and ensuring the consistent application of nationwide standards, legislation, policies and processes that need to be adhered to in order to ensure systems compatibility on a regional, national and international level.

We however also offer a number of additional considerations for the effective implementation of eHealth systems in South Africa, which have been found to not be effectively addressed in the South African eHealth strategy:

- Various stakeholder groups such as different groups of consumers, health care providers, policymakers and government departments need to be consulted more effectively. This must be done to ensure their value propositions are addressed and that systems adequately address their needs.

- Specific planning and support need to be put in place to consider an uptake plan for ICT application. Barriers to adoption have been identified in this article to include on the supply side but also demand side. For instance, in order for ICTs to be rolled out on a large scale, consideration must be given to ICT and eHealth literacy of the target populations of these interventions, which is not specifically addressed in the eHealth strategy.

- Much work also still remains to develop sustainable business models for ICT and eHealth tools for a thriving
eHealth industry where the private sector can take the lead to develop solutions.

In conclusion, it must be stressed that the temporal element of the implementation of the eHealth strategy needs to be taken into consideration. To the end of outlining priorities and the sequence of implementation, the authors propose a phased approach for the range of suggested priority areas for a medium-term planning framework. We outlined factors around coordination, capacity development and the ICT environment (see Figure 5).

Phase 1: An enabling environment and migration to a single platform: As the first and the currently ongoing phase towards the implementation of eHealth, the process of characterising the policy context and the nature of government support going forward should be prioritised. As has been shown in the analysis and review of the South African eHealth strategy, standardisation, interoperability, privacy and data protection have been identified as high priority areas to address.

Furthermore, infrastructure development, the role of government procurement in stimulating the demand side, the development of appropriate business models and human resources capacity development need to be carefully conceptualised during the initial phase of implementing the eHealth strategy.

Phase 2: Driving uptake and upscaling: Following the development of an enabling environment, the implementation of standards and incentive systems should be prioritised to ensure support for the wide-scale uptake of eHealth technologies. Here, issues such as the development of ICT infrastructure and increasing access to such resources should assist in the process.

Specific planning and support need to be put in place to consider an uptake plan for eHealth. Here, barriers to adoption have been identified considering issues on the supply side but also on the demand side. For instance, on the demand side, ICT and eHealth literacy need to be addressed along with government procurement planning to create a market and to stimulate technology development.

Phase 3: Focus on stimulating demand and mainstreaming eHealth: A final phase for the large-scale roll-out and adoption of ICTs in eHealth programmes will entail the integration into mainstream health services and a drive towards infrastructure maturity. ICT infrastructure could be leveraged to create rich databases for planning support and service delivery monitoring.

Finally, during this phase, the eventual success and sustainable continued existence of the additional services and benefits for ICT support on health programmes is reliant on the successful entry of private sector players through the implementation of sustainable business models. 


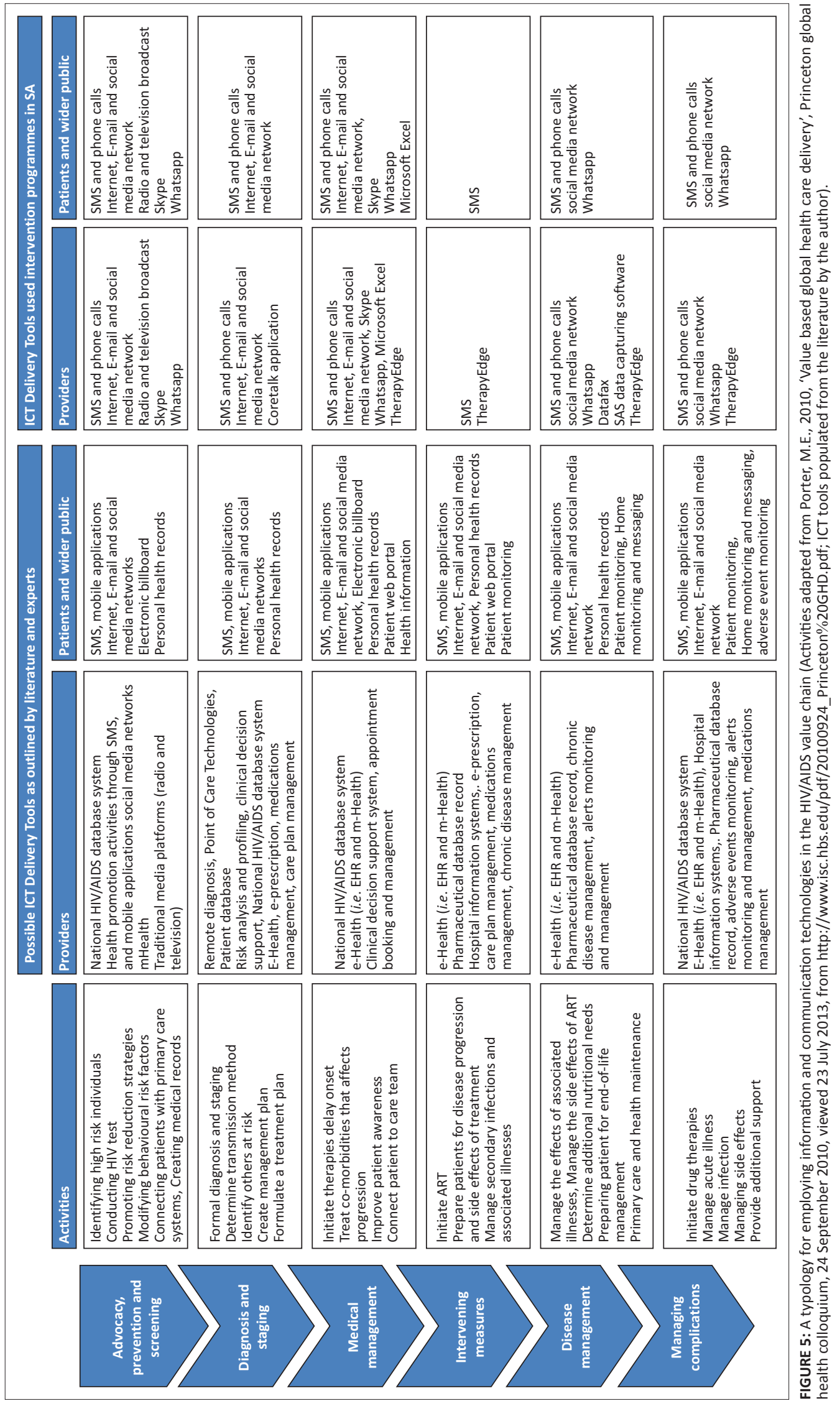




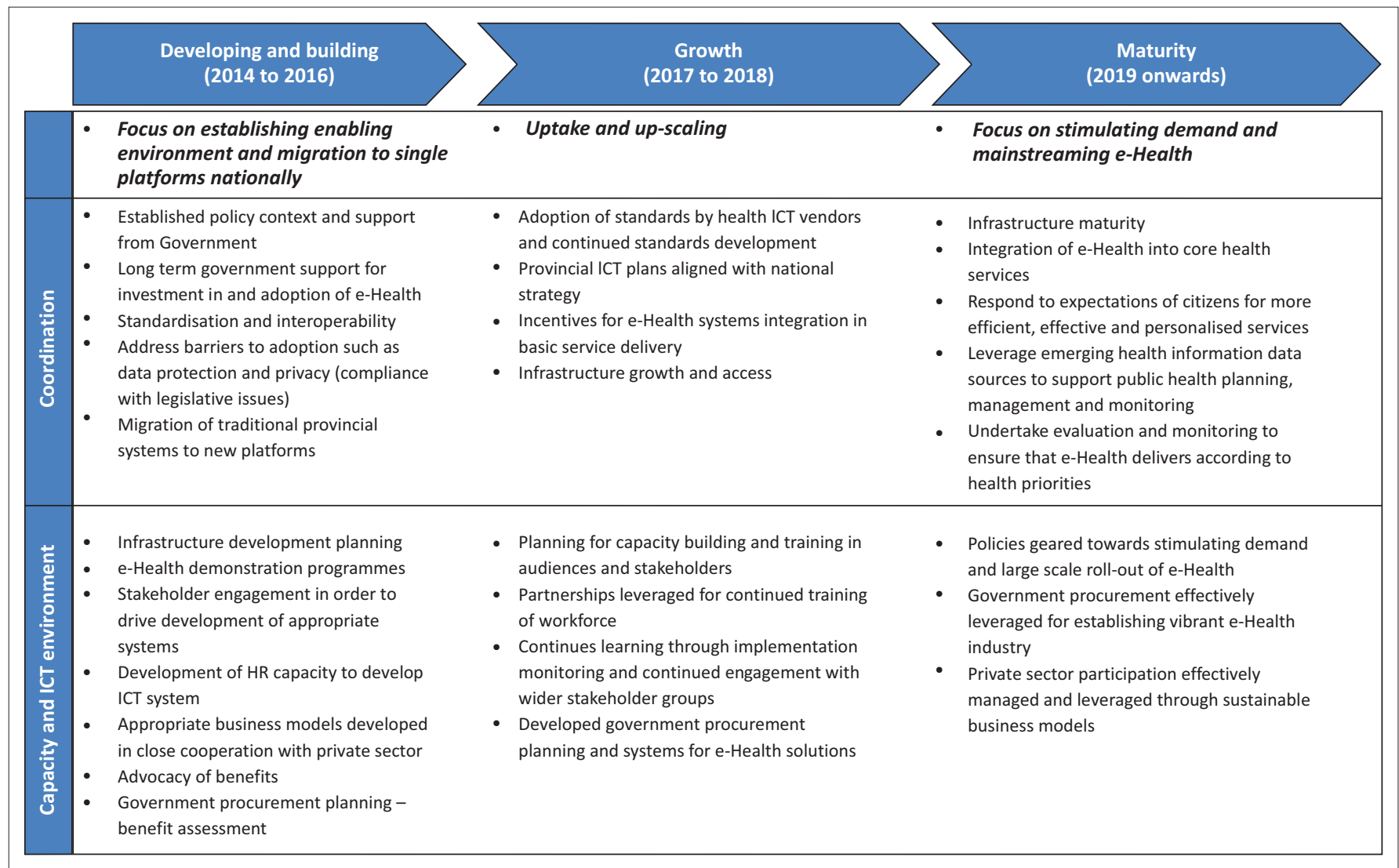

FIGURE 6: eHealth development roadmap.

\section{Acknowledgements Competing interests}

The authors declare that they have no financial or personal relationship(s) that may have inappropriately influenced them in writing this article.

\section{Author's contributions}

The primary research in this article was completed as part of B.D.O.'s (University of Pretoria) master's thesis, as supervised by S.S.G. (University of Pretoria). Both authors contributed to the article conceptually and in the write-up.

\section{References}

Akinsola, O.S., Herselman, M.E. \& Jacobs, S.J., 2005, 'ICT provision to disadvantaged urban communities: A study in South Africa and Nigeria', International Journal of Education and Development using Information and Communication Technology (IJEDICT) 1(3), 19-41.

Aurumo, J., Inkilainen, A. \& Kauremaa, J., 2005, 'The role of information technology in supply chain management', viewed 24 March 2013, from http://legacy-tuta.hut. fi/logistics/publications/NOFOMA_2005 IT in SCM.pdf

Bollinger, L. \& Stover, J., 1999, 'The economic impact of AIDS in South Africa', the POLICY project, Futures Group International, viewed n.d., from http://www.heartintl.net/HEART/030106/TheEconomiclmpact.pdf

Chandani, Y., 2006, 'Inventory management: Distribution, ICS, LMIS', viewed 23 April 2013, from www.who.int/entity/hiv/amds/(2.8)InvMgmtChallengesfinal.ppt

De Tolly, K. \& Alexander, H., 2009, 'Innovative use of cellphone technology for HIV/ AIDS behaviour change communications: 3 pilot projects', viewed 27 January 27 2015, from http://www.w3.org/2008/10/MW4D_WS/papers/kdetolly.pdf

Department of Health (DOH), 2011, 'Human resources for health South Africa 2030: Draft HR strategy for the health sector 2012/13 - 2016/17: Consultation document V5', viewed 06 June 2013, from http://www.info.gov.za/view/ DownloadFileAction?id=152426
DOH, 2012a, 'Development of eHealth strategy for South Africa', report delivered at WHO-ITU meeting National eHealth strategy development: Country experience and next steps, Geneva, Switzerland, 24-26 July 2012.

DOH, 2012b, 'eHealth Strategy South Africa 20122016', viewed 23 October 2013 , from http://www.lib.uct.ac.za/governmentpublications/govpub-news/ehealthstrategy-south-africa-2012-2016/

Eba, P.M., 2007, 'Stigma[ta]: Re-exploring HIV-related stigma. AIDS Review 2007', Centre for study of AIDS, University of Pretoria, Pretoria, South Africa.

Foster, R., 2012, 'The development of the South African eHealth Strategy assessed against the recommendations of the WHO / ITU eHealth strategy toolkit', Journal of the International Society for Telemedicine and eHealth 1(2), 2013.

Geers, B. \& Page, S., 2007, 'ICT for mitigating HIV/AIDS in Southern Africa', report, 2nd edn., Swedish Program for ICT in Developing Regions (SPIDER), Stockholm, Sweden.

Health Charter, 2005, 'CHARTER: The charter of the public and private health sectors of the Republic of South Africa', viewed 06 June 2013, from http://www. capetown.gov.za/en/CityHealth/Documents/Legislation/Health\%20Charter\%20 of $\% 20$ South $\% 20$ Africa.pdf

Kaiser Family Foundation, 2012, 'The global HIV/AIDS Epidemic: Fact sheet', viewed 12 March 2013, from http://www.kff.org/hivaids/upload/3030-17.pdf

Knight, R., 2006, 'South Africa 2006: Population and HIV/AIDS', South Africa delegation briefing paper, viewed 18 September 2014, from http://richardknight.homestead. com/files/SouthAfrica2006-PopulationanandHIV-AIDS.pdf

Lawn, J.E. \& Kinney M.V., 2009, 'The Lancet: Health in South Africa: An executive summary for The Lancet series', viewed 05 June 2013, from http://download. thelancet.com/flatcontentassets/series/sa/sa_execsum.pdf

Marais, H., 2005, 'Buckling: The impact of AIDS in South Africa 2005', Centre for study of AIDS, University of Pretoria, viewed 18 September 2014, from http://www. sarpn.org/documents/d0001789/

Ntuli, A., Ijumba, P., McCoy, D., Padarath, A. \& Berthiaume, L., 2003, 'HIV/AIDS and health sector responses in South Africa. Treatment access and equity: Balancing the act', Regional Network for Equity in Health in Southern Africa (EQUINET) discussion paper number 7, September 2003.

Porter, M.E., 2010, 'Value based global health care delivery', Princeton global health colloquium, 24 September 2010, viewed 23 July 2013, from http://www.isc.hbs. edu/pdf/20100924_Princeton\%20GHD.pdf

Rachel, K., 1999, 'Sexual behavioural change for HIV: Where have theories taken us?', UNAIDS, viewed 05 March 2013, from http://www.unaids.org/en/media/unaids/ contentassets/dataimport/publications/irc-pub04/jc159-behavchange_en.pdf

Rhatigan, J., Jain, S., Mukherjee, S.J. \& Porter, M.E., 2009, 'Applying the care delivery value chain: HIV/AIDS care in resource poor settings', Harvard Business School
working paper 09-093, viewed 23 July 2013, from http://www.hbs.edu/faculty/ Publication\%20Files/09-093.pdf 
Scheibe, A., Brown, B. \& Bekker, L.G., 2012, 'ICT \& HIV prevention: Experiences from a biomedical HIV prevention trial among men who have sex with men
(MSM) in Cape Town, South Africa', viewed 12 March 2013, from http://www. digitalcultureandeducation.com/volume-4/thehive_3004_html/

Shisana, O., Rehle, T., Simbayi, L.C., Zuma, K., Jooste, S., Zungu, N., et al., 2014, South African National HIV prevalence, incidence and behaviour survey, 2012, HSRC Press, Cape Town, South Africa.

Sikhakhane, B. \& Lubbe, S., 2005, 'Preliminaries into problems to access information - the digital divide and rural communities', South African Journal of Information - the digital divide and rural
Management $7(3), 12$ pages.

UNAIDS, 2011, Global HIV/AIDS response. Epidemic update and health sector progress towards universal access. Progress report, viewed 12 March 2013 from http://www.unaids.org/en/media/unaids/contentassets/documents/ unaidspublication/2011/20111130_ua_report_en.pdf]
UNDP, 2010, Millennium development goals: Country report 2010, viewed 12 March 2013, from http://www.za.undp.org/content/dam/south_africa/docs/Reports/ The_Report/MDG_October-2013.pdf

Venter, F., 2013, HIV Treatment in South Africa: The challenges of an increasingly successful antiretroviral programme. South African health review $2012-2013$ viewed 10 September 2014, from http://www.hst.org.za/publications/southafrican-health-review-2012/13

Weeks, R.V., 2012, 'A technology perspective of healthcare services management', Acta Commercii 2012, 173-185.

World Health Organization (WHO), 2012, National eHealth strategy toolkit, viewed 10 February 2014, from https://extranet.who.int/iris/restricted/handle/10665/ 75211 